Original research article

\title{
Longitudinal study of postural and locomotor function development in clients with brain damage
}

\author{
Markéta Bendová ${ }^{*}$, Martina Hartmanová ${ }^{1}$, Jitka Vacková ${ }^{1}$, Marcela Míková ${ }^{1,2}$, Anna Kuželková ${ }^{1,3}$ \\ ${ }^{1}$ University of South Bohemia in České Budějovice, Faculty of Health and Social Sciences, České Budějovice, Czech Republic \\ 2 České Budějovice Hospital a. s., Department of Rehabilitation, České Budějovice, Czech Republic \\ ${ }^{3}$ Charles University and General University Hospital in Prague, The First Faculty of Medicine, Department of Rehabilitation Medicine, Prague, \\ Czech Republic
}

\begin{abstract}
Background: Acquired brain injury (ABI) is a disease that causes severe disability. For this reason, we established an interprofessional rehabilitation team consisting of physicians, physiotherapists, occupational therapists, and social workers operating in home settings - in an effort to minimize the consequences of long-term disability.

Objectives: Evaluate the development of postural and balance functions (over a 9-month period) in 17 clients with ABI undergoing individualized 3-month physiotherapy in the home setting.

Methods: Berg Balance Scale (BBS) and Timed Up and Go test (TUG) were used to quantify the functional status of the clients. A total of 4 assessments were completed at the initial, 3 months, 6 months, and final 9-months examinations.

Results: According to BBS and TUG, 15 clients showed an improvement in their balance functions after the intervention; 2 clients were unable to complete the TUG, and 6 clients remained at risk of falling.

Conclusions: Our results showed a clear benefit of the physiotherapeutic intervention. However, 6 months after completion, one-third of the clients had worse results on the TUG; although 15 clients continued to improve according to the BBS. This indicates the higher sensitivity of the TUG test for evaluating balance functions, and that physiotherapeutic interventions should be prolonged, particularly in clients with a Functional Independence Measure instrument (FIM) of less than 6 points.
\end{abstract}

Keywords: Acquired brain injury; BBS; FIM; Risk of falls; Stability evaluation; TUG test

\section{Introduction}

Brain damage of non-traumatic origin mainly includes cerebrovascular events (CVE), also known as ictus, apoplexy, stroke, and brain infarction, i.e., sudden damage to brain functions caused by vascular changes (Carraro, 2002; McIntyre et al., 2015). Cerebrovascular events rank among the most serious disabling diseases with neurological causes (Ambler, 2011). The mean annual incidence of CVE in Europe is 150 per 100,000 inhabitants. Currently, the incidence in the Czech Republic is almost double that and the incidence in the European Union has increased every year by $1-1.5 \%$ (IHIS CR, 2018). This unfavorable trend is caused not only by the aging of the population but also by an increasing incidence rate of this acute and serious disease in ever younger citizens of productive age (Čeledová et al., 2010).

The standard of medical care for patients with acquired brain injury (ABI) is outstanding in the Czech Republic; a nationwide network of 32 medical ictus centers (IC) and 13 larger complex cerebrovascular centers (CCC) exists, providing complex diagnostic and therapeutic care to patients with CVE (MoH, 2015). Despite this advanced care, only $10-15 \%$ postCVE patients are transferred to an acute rehabilitation ward (Hlinovský et al., 2016). There is a serious shortage of beds in early rehabilitation departments. As a result, the vast majority of clients in need of rehabilitation are transferred to aftercare medical institutions that are unable to provide adequate rehabilitation, causing many clients to remain severely disabled (MoH, 2010). The clients' quality of life is directly dependent on prompt initiation of neurorehabilitation, provided continuously from the onset of the disease, in the form of inpatient and later outpatient rehabilitation, up to social, family, and occupational reintegration (Lippertová-Grünerová, 2015).

When the client's condition has been stabilized, verticalization and locomotion can be started. These are preconditions not only for subsequent walking but also as stimulation for the circulatory system, prevention of osteoporosis, pneumonia, contractures, etc. Typically, CVE clients exhibit impairment of isolated movements, smooth and effective movements, proprioception and balance (Dungl, 2005; Mayer, 2002). Disorders of balance, movement coordination, and cognitive functions may

\footnotetext{
* Corresponding author: Markéta Bendová, University of South Bohemia in České Budějovice, Faculty of Health and Social Sciences, J. Boreckého 27, 37011 České Budějovice, Czech Republic; e-mail: bendovam@zsf.jcu.cz http://doi.org/10.32725/kont.2021.023
} 
manifest as an increased risk of falls and negatively impact gait (Vařeka, 2002). Reducing the fear of falling through walking rehabilitation includes non-negligible psychological motivation for the patient and an improved sense of self-sufficiency, communication and can result in a substantial enhancement in the quality of life (Burget, 2015; Mikula, 2008).

Home-based coordinated rehabilitation could be a solution in which the therapeutic component of rehabilitation is understood as the foundation that affects the success rate of subsequent processes including social rehabilitation (Čeledová and Čevela, 2011). During the client's transition to home care, uninterrupted care should be ensured by the entire team of specialists; the main purpose of a coordinated rehabilitation approach is to increase client independence and enhance client self-confidence (Kolář et al., 2012). During this period, the role of the general practitioner is also essential as he/she will be the first physician to interact with the client after discharge to the home setting - and will also be responsible for subsequent medical supervision (Kolář et al., 2012).

\section{Materials and methods}

The aim of this study is to evaluate the development of postural and balance functions over a 9-month period, and the effect of a 3-month, in-home, physiotherapeutic intervention on locomotor functions and on the risk of falls in clients with acquired brain injury.

21 clients, mostly after a CVE, who had received treatment at the Departments of Neurology and Rehabilitation at České Budějovice Hospital, were enrolled in the project. The physician, along with the occupational therapist, selected prospective patients based on a diagnosis of ABI and a patient's permanent address being within $30 \mathrm{~km}$ of České Budějovice. Other essential criteria included the preservation of the client's ability to communicate, cooperation of the client and his/her family, and degree of client motivation for in-home rehabilitation and follow-up. Regarding the longitudinal follow-up of postural functions development parameters, we collected data and continuously measured a total of 17 clients with ABI over a 9-month period directly from their homes (Table 1). Data were collected from October 2016 to December 2018. Four clients did not complete the project, mainly due to moving to a new residence outside the predetermined area by a considerable distance. By signing the informed consent form, clients expressed their consent with participation in the research project, anonymous data processing and the publication of obtained data. The implementation of the research was approved by the Ethics Committee of the Faculty of Health and Social Sciences at the University of South Bohemia in České Budějovice.

All clients received a 3-month, twice weekly, in-home, intensive physiotherapy program; every session lasted one hour, and the therapy was individualized based on the client's current needs. We used a neurophysiological rehabilitation program where a combination of various methods was utilized to provide mainly task-oriented functional therapy related to specific goals (e.g., pick up a cup, improve gait effectiveness, walk down a set of stairs, leave the house, etc.), and cognitive therapy. The therapy was individualized with respect to each client and was oriented towards facilitating the learning of higher-quality movements designed to stabilize the gait and convalesce the movements needed for everyday living. The clients were also motivated to engage in autotherapy.

\begin{tabular}{|c|c|c|c|c|c|}
\hline Client & $\begin{array}{l}\text { Year of } \\
\text { birth }\end{array}$ & Age & Sex & Diagnosis & $\begin{array}{c}\text { Clinical } \\
\text { presentation }\end{array}$ \\
\hline KL1 & 1941 & 77 & M & iCVE & l. $d x$ \\
\hline HBZ2 & 1966 & 52 & F & iCVE & l. $\sin$. \\
\hline ŠA3 & 1947 & 71 & F & iCVE & l. $\sin$. \\
\hline KF4 & 1946 & 72 & M & iCVE & l. $\sin$. \\
\hline CM6 & 1940 & 78 & $\mathrm{~F}$ & iCVE & l. $d x$ \\
\hline RM7 & 1936 & 82 & F & iCVE & l. $\sin$. \\
\hline LM10 & 1948 & 70 & $\mathrm{M}$ & iCVE & l. $d x$ \\
\hline TM11 & 1944 & 74 & F & iCVE & l. $\sin$. \\
\hline MR12 & 1970 & 48 & M & hCVE & l. $\sin$. \\
\hline KT13 & 1976 & 42 & M & craniotrauma & l. sin. \\
\hline ML14 & 1960 & 58 & M & iCVE & l. $\sin$. \\
\hline BV15 & 1955 & 63 & M & iCVE & l. $d x$ \\
\hline RB17 & 1941 & 77 & F & iCVE & l. $\sin$. \\
\hline KL18 & 1983 & 35 & M & polytrauma & l. sin. \\
\hline RM19 & 1949 & 69 & $\mathrm{~F}$ & iCVE & l. $\sin$. \\
\hline KJ20 & 1932 & 86 & M & $\mathrm{iCV}$ & l. $\sin$. \\
\hline BP21 & 1976 & 42 & F & hCVE & tetraplegic \\
\hline
\end{tabular}

Note: F - female; M - male; hCVE - hemorrhagic cerebrovascular event; iCVE - ischemic cerebrovascular event.

The entire interprofessional team was present for the first visit at each client's home; the team included one physiotherapist, one occupational therapist, and two social workers. They performed an overall assessment and testing of the client with respect to individual specializations, including interviews with family members. The following were used to gather client information for our database: medical history, kinesiology examination, the FIM instrument, the Timed Up and Go test (TUG), and the Berg Balance Scale (BBS).

Occupational therapy and social work were provided individually based on the client's needs. The occupational therapist detected partial function deficits and self-care in the daily activities, recommended compensatory aids and adjustment to the apartment. The social worker coordinated a multidisciplinary team, mapped the social situation, provided information support (social security benefits), mediated contact with the social environment, assisted in asserting rights, legitimate interests, handling personal matters, and provided social activating activities.

Measurements were obtained at baseline testing (identified as FIM 0, TUG 0, BBS 0), post-physiotherapy intervention testing at 3 months (FIM 3, TUG 3, BBS 3), and 6 months, (TUG 6, BBS 6) and 9 months of follow up testing (TUG 9, BBS 9). All tests were carried out using a standard methodology.

The FIM instrument is a licensed standardized tool assessed by a trained occupational therapist to evaluate patient self-sufficiency and individual levels of functional disability. It uses a 7-point scale for quantification ( 1 = full assistance to 7 = full self-sufficiency) (The FIM Instrument ${ }^{\circledR}, 2014$ ). We used FIM instrument as an objective tool for evaluation of rehabilitation efficacy and for client classification into groups.

The standardized Timed Up and Go test (TUG) (Table 2) was designed to assess a client's functional mobility, postur- 
al stability while walking, and the function of the vestibular apparatus (Rehabilitation measures database, 2010). The test involves standing up from a chair and walking at the normal pace of a safe gait to a mark that is 3 meters from the chair, turning around, walking back, and sitting down on the chair, while a therapist measures the time needed to perform the task (Podsiadlo and Richardson, 1991; Son and Park, 2018). If needed, the client can use whatever walking aide they typically use, but no personal assistance should be provided during the test (Podsiadlo and Richardson, 1991). The test is repeated 3 times and the mean time of all 3 results was used.

Table 2. Normative values for the Timed Up and Go test for various age categories (Bohannon, 2006)

\begin{tabular}{lcc}
\hline Age category & Time in seconds & (95\% confidence interval) \\
\hline $60-69$ years & 8.1 & $(7.1-9.0)$ \\
\hline $70-79$ years & 9.2 & $(8.2-10.2)$ \\
\hline $80-99$ years & 11.3 & $(10.0-12.7)$ \\
\hline
\end{tabular}

The Berg Balance Scale (BBS) evaluates static and dynamic postural stability as they related to the risk of falls. This is a balance test with 14 tasks. Every task is scored from 0 to 4 , where 4 means full performance of the task (Berg et al., 1989; 1992). The maximum score is 56 points (Table 3 ).

Table 3. Evaluation of the Berg Balance Scale (Berg et al., 1992)

Berg Balance Scale - maximum score 56 points

\begin{tabular}{ll}
\hline $0-20$ points & High risk of falls \\
\hline $21-40$ points & Moderate risk of falls \\
\hline $41-56$ points & Low risk of falls \\
\hline
\end{tabular}

\section{Results}

Each client was evaluated separately as a case study; however, we divided the clients into three groups according to their baseline FIM scores: clients with FIM of more than 6 points, clients with FIM of 5 to 6 points, and clients with FIM of less than 5 points.

The first group - with FIM of more than 6 points - included 4 clients (Table 4). According to the FIM instrument instruc- tions, clients with an FIM of over 6 points do not require assistance and are able to safely manage all common daily activities without a risk of falling and suffering injury and within a reasonable time interval (use of compensation aids is allowed) (The FIM Instrument ${ }^{\circledR}, 2014$ ). Our clients with a baseline FIM of more than 6 points did not need any compensation aids to walk and their overall assessment was as follows: three clients (HBZ2, TM11, BV15) were at risk of falls at the baseline according to the TUG 0 , and one client (TM11) was at high risk of falls according to the BBS 0 . An identical trend was observed in these clients in terms of the times needed to perform the TUG 3, where all clients improved after a 3-month physiotherapy intervention (Chart 1). The TUG 6 follow-up measurements showed a slight worsening in three clients (CM6, TM11, BV15) (no further rehabilitation attended); one client (HBZ2) improved (individually arranged cognitive function training to address her slower psychomotor pace and a tendency to tire rapidly under mental load). The TUG 9 follow-up measurements showed an improvement in all clients. These improvements were very similar to those achieved after completion of the therapy (TUG 3). Three clients moved fully into the no risk of falls range (HBZ2, CM6, BV15), and one client (TM11) exceeded the standardized range by 0.4 seconds only. Relative to the BBS scores, all clients' balance skills improved over the entire course of the follow-up - without any transient worsening of postural functions. After summarizing clients with FIM of more than 6 points, our measurements suggest that the TUG test was more sensitive to the risk of falling than the BBS.

The group with FIM of 5 to 6 points included 9 clients (Table 5). According to FIM instrument instructions, these clients did not need assistance but may require supervision when performing certain tasks; they often suffer from cognitive deficits, which may prevent them from performing a given test properly or during the specified time period (The FIM Instrument ${ }^{\circledR}$, 2014). In our case, three clients needed compensation aids to walk (French crutches in clients LM10, MR12 and a rollator in client KJ20). All clients were at the risk of falls based on the TUG 0 scores. Based on the BBS 0, seven clients (ŠA3, LM10, MR12, KT13, RB17, RM19, KJ20) were at the risk of falls. All clients improved in both tests after the 3-month rehabilitation intervention (Chart 2), nevertheless 8 clients remained at risk of falls based on TUG 3 scores. Based on BBS 3 scores, only three clients were at risk of falls. The first follow-up measurement TUG 6 usually showed a worsening and indicated an increase of the risk of falls in 5 clients (ŠA3, MR12, KT13, RB17, KJ20). With regards to BBS 6, four clients (KT13, RB17, RM19, KJ20) worsened. Client LM10 passed away before the TUG 6 and BBS 6 measurements, and therefore these follow-up data

Table 4. Measurement results for clients with FIM of more than 6 points

\begin{tabular}{lcccccccccccccc} 
Client & Age & Sex & FIM 0 & FIM 3 & TUG 0 & TUG 3 & TUG 6 & TUG 9 & BBS 0 & BBS 3 & BBS 6 & BBS 9 & RHB 3-6 \\
\hline HBZ2 & 52 & F & 6.27 & 6.72 & 9 & 8 & 7 & 7 & 56 & 56 & 56 & 56 & YES \\
CM6 & 78 & F & 6.39 & 6.94 & 13.4 & 10.3 & 11 & 9.8 & 48 & 52 & 56 & 56 & NO \\
TM11 & 74 & F & 6.72 & 6.83 & 18.2 & 12.4 & 13 & 10.6 & 10 & 40 & 47 & 47 & YES \\
BV15 & 63 & M & 6.33 & 6.89 & 8.7 & 7.3 & 9.2 & 8.4 & 45 & 53 & 54 & 55 & NO \\
\hline
\end{tabular}

Note: FIM 0 - FIM instrument baseline score; FIM 3 - FIM instrument after 3-month coordinated rehabilitation score; TUG 0 - Timed Up and Go test baseline assessment in seconds; TUG 3 - Timed Up and Go test after the 3-month coordinated rehabilitation in seconds; TUG 6 - Timed Up and Go test 6 months after entering the project (in seconds); TUG 9 - Timed Up and Go test 9 months after entering the project (in seconds); BBS 0 - Berg Balance Scale baseline score; BBS 3 - Berg Balance Scale score after the 3-month coordinated rehabilitation; BBS 6 - Berg Balance Scale score 6 months after entering the project; BBS 9 - Berg Balance Scale score 9 months after entering the project; RHB 3-6 - further rehabilitation after our intervention ended. 


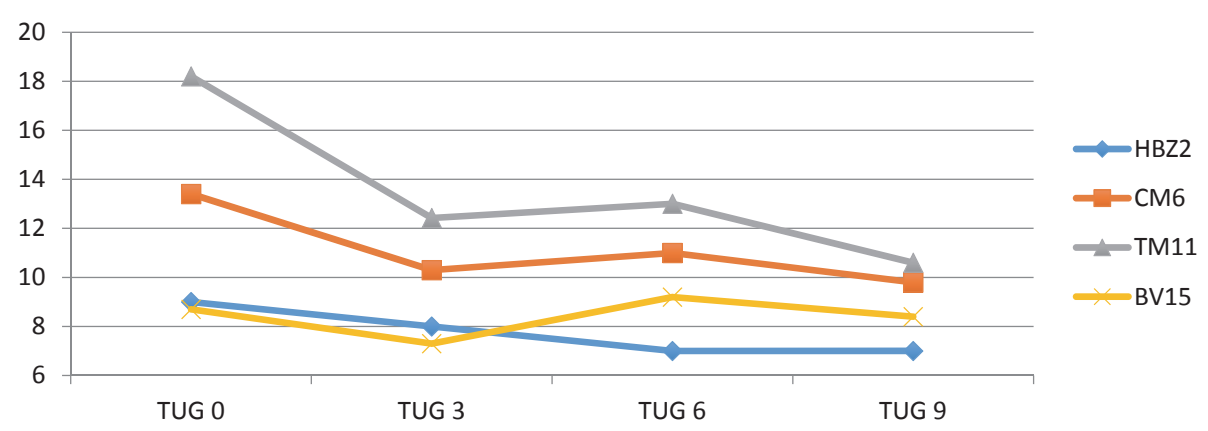

Chart 1. Development of the TUG test results in clients with a FIM of more than 6 points

Table 5. Measurement results for clients with FIM of 5 to 6 points

\begin{tabular}{lcccccccccccccc} 
Client & Age & Sex & FIM 0 & FIM 3 & TUG 0 & TUG 3 & TUG 6 & TUG 9 & BBS 0 & BBS 3 & BBS 6 & BBS 9 & RHB 3-6 \\
\hline SA3 & 71 & F & 5.83 & 5.89 & 12.7 & 7.8 & 9.7 & 7.2 & 20 & 36 & 47 & 48 & YES \\
RM7 & 82 & F & 5.5 & 6.11 & 17.5 & 14.3 & 10.8 & 12.9 & 48 & 52 & 53 & 53 & NO \\
LM10 & 70 & M & 5.61 & 6.33 & 15.5 & 11.1 & x & x & 23 & 51 & x & x & x \\
MR12 & 48 & M & 5.83 & 6.5 & 16.2 & 11.7 & 12.6 & 19.1 & 13 & 32 & 41 & 41 & YES \\
KT13 & 42 & M & 5.56 & 6.5 & 24 & 16 & 18 & 15 & 35 & 42 & 40 & 45 & YES \\
RB17 & 77 & F & 5.11 & 6.17 & 23.3 & 13.6 & 19.2 & 21.4 & 31 & 40 & 39 & 39 & NO \\
KL18 & 35 & M & 5 & 6.44 & 12 & 10 & 10 & 10 & 50 & 56 & 56 & 56 & NO \\
RM19 & 69 & F & 5.72 & 6.44 & 18.9 & 15.2 & 12.3 & 12.8 & 29 & 52 & 47 & 47 & NO \\
KJ20 & 86 & M & 5.22 & 5.5 & 35.3 & 24.7 & 29.5 & NA & 13 & 24 & 22 & 22 & NO \\
\hline
\end{tabular}

Note: FIM 0 - FIM instrument baseline score; FIM 3 - FIM instrument after 3-month coordinated rehabilitation score; TUG 0 - Timed Up and Go test baseline assessment in seconds; TUG 3 - Timed Up and Go test after the 3-month coordinated rehabilitation in seconds; TUG 6 - Timed Up and Go test 6 months after entering the project (in seconds); TUG 9 - Timed Up and Go test 9 months after entering the project (in seconds);

BBS 0 - Berg Balance Scale baseline score; BBS 3 - Berg Balance Scale score after the 3-month coordinated rehabilitation; BBS 6 - Berg Balance Scale score 6 months after entering the project; BBS 9 - Berg Balance Scale score 9 months after entering the project; RHB 3-6 - further rehabilitation after our intervention ended.

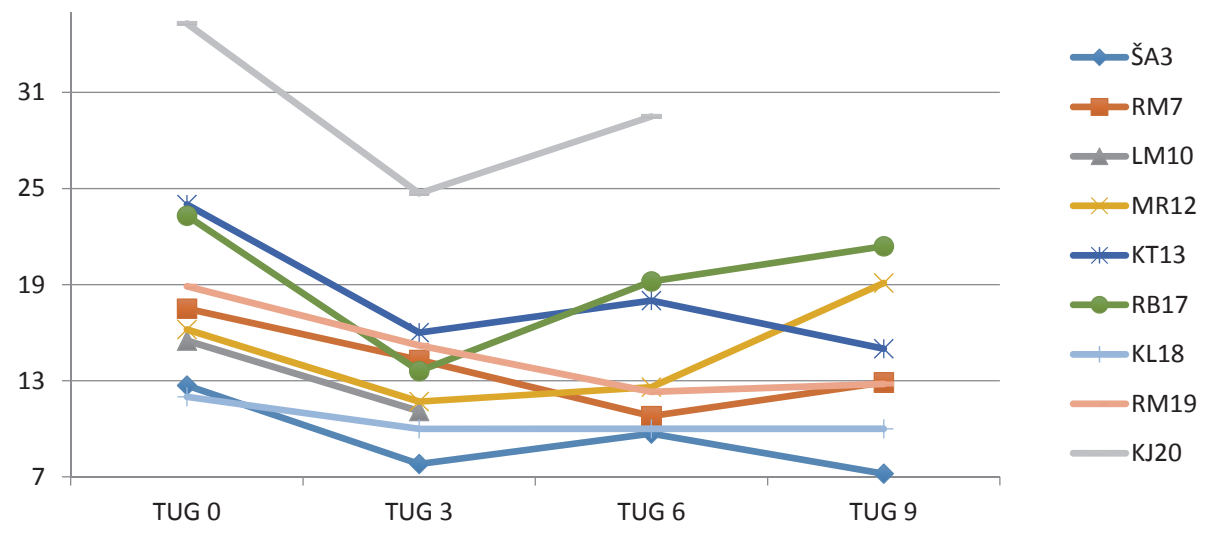

Chart 2. Development of the TUG test results in clients with a FIM of 5 to 6 points

are missing from Table 6. At the end of the 9-month follow-up period a slight improvement appeared, nevertheless the risk of falls remained in 6 clients (RM7, MR12, KT13, RB17, KL18, RM19, KJ20) based on TUG 9 scores, but only in two clients (RB17, KJ20) based on BBS 9 scores. Client KJ20 had a second cerebrovascular event one week before the final follow-up measurements, therefore he was unable to perform the TUG 9 assessment.
According to FIM instrument instructions, clients with a baseline FIM of less than 5 points required $50 \%$ physical assistance to perform ADL activities (The FIM Instrument ${ }^{\circledR}$, 2014). The baseline FIM scores of our 4 clients (Table 6) showed that they were very dependent on the assistance of another person and had problems completing the functional tests. Clients ML14 and BP21 were unable to complete the TUG and BBS tests because they were not able to sit down or stand up inde- 
pendently. These two clients needed a high walking frame and the assistance of another person to walk. In these two clients, the efficacy of the intervention was based on their FIM scores, overall kinesiology and occupational therapeutic assessment. Two clients (KL1, KF4) needed a rollator to perform TUG tests due to their unstable standing position and gait, but both clients improved after physiotherapy intervention (Chart 3). Client KF4 showed a gradual worsening on TUG 6 and 9. Client
KL1 completed the TUG 6 and TUG 9 without any walking aids and assessment times considerably improved. Nevertheless, both clients remained at high risk of falls based on TUG tests. BBS scores showed improvements in both clients, and one (KL1) was no more at risk of falls. Both clients continued to need assistance to perform everyday activities; unfortunately, they did not attend any subsequent rehabilitation.

Table 6. Measurement results for clients with FIM of less than 5 points

\begin{tabular}{lcccccccccccccc} 
Client & Age & Sex & FIM 0 & FIM 3 & TUG 0 & TUG 3 & TUG 6 & TUG 9 & BBS 0 & BBS 3 & BBS 6 & BBS 9 & RHB 3-6 \\
\hline KL1 & 77 & M & 4.39 & 4.78 & 27.6 & 21.1 & 20.2 & 18.7 & 14 & 39 & 43 & 46 & NO \\
KF4 & 72 & M & 3.28 & 5.61 & 90 & 64 & 76 & 90 & 6 & 10 & 10 & 10 & NO \\
ML14 & 58 & M & 3.67 & 3.94 & NA & NA & NA & NA & 0 & 5 & 5 & 7 & YES \\
BP21 & 42 & F & 1.56 & 2.17 & NA & NA & NA & NA & 0 & 0 & 0 & 0 & YES \\
\hline
\end{tabular}

Note: FIM 0 - FIM instrument baseline score; FIM 3 - FIM instrument after 3-month coordinated rehabilitation score; TUG 0 - Timed Up and Go test baseline assessment in seconds; TUG 3 - Timed Up and Go test after the 3-month coordinated rehabilitation in seconds; TUG 6 - Timed Up and Go test 6 months after entering the project (in seconds); TUG 9 - Timed Up and Go test 9 months after entering the project (in seconds);

BBS 0 - Berg Balance Scale baseline score; BBS 3 - Berg Balance Scale score after the 3-month coordinated rehabilitation; BBS 6 - Berg Balance Scale score 6 months after entering the project; BBS 9 - Berg Balance Scale score 9 months after entering the project; RHB 3-6 - further rehabilitation after our intervention ended.

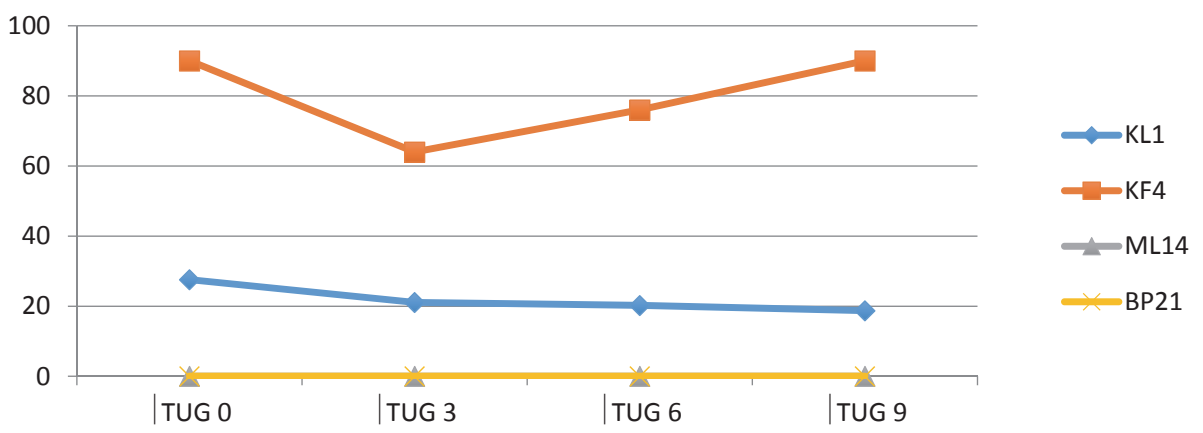

Chart 3. Development of the TUG test results in clients with a FIM of less than 5 points

\section{Discussion}

Part of our project consisted of developing a system of inter-professional cooperation for community-based rehabilitation and providing coordinated interprofessional rehabilitation managed by specialists in physiotherapy, occupational therapy, and social work in home settings.

Unfortunately, many patients did not meet the inclusion criteria for the project, and only 21 clients with a diagnosis of $\mathrm{ABI}$ were able to participate in our study. A travel distance of less than $30 \mathrm{~km}$ was the first essential criterion, because the physiotherapeutic intervention was provided twice weekly for 3 months in the client's home. Each client received almost 30 home visits from a physiotherapist. In the two most serious cases (ML14 and BP21), an occupational therapist also visited once a week.

Standardized functional tools (the TUG test and the BBS) were used to quantify and interpret the benefits of the physiotherapy intervention, which is important for the motivation of the therapist as well as the client. Functional tests are an essential tool and rank among the most used evaluation techniques for assessing stability while standing and walking
(Bizovská et al., 2017). As reported by Kolář et al. (2015), the gait as a basic locomotion stereotype reflects all disorders of the human body, especially disorders of the motor apparatus and the nervous system. The quality of the gait is commonly affected by balance disorders that can lead to an increased risk of falls (Kolář et al., 2015). Fear of falling can also lead to serious psychological consequences. Additionally, as movement becomes limited, muscle strength declines, which can lead to increased fatigue and earlier fatigue onset; this can cause a reduction in social contacts and activities, which can manifest as reduced quality of life for clients (Bizovská et al., 2017).

Of all the clinical tests used to evaluate locomotion, balance, and the risk of falls, we chose the TUG test and the BBS. These are quick and easy to complete with no special modifications of the home. Moreover, these tests are easy for clients to understand. The TUG test has proven validity and reliability (inter-rater reliability ICC $=0.99$ ), especially in geriatric patients and patients with neurological diseases where its validity is supported by a high correlation with results from other functional tests (Alghwiri and Whitney, 2012; Andersson et al., 2006; Bohannon, 2006). Although Barry et al. (2014) support using a simpler assessment in which clients with scores of more than 13.5 seconds are considered to be at high risk of 
falls, our research presents more accurate normative data for the TUG test according to Bohannon (2006) for various age categories, since Bohannon (2006) performed a meta-analysis of 21 studies involving more than 4,000 clients.

Using repeated TUG and BBS assessments over a longer time period of 9 months enabled us to observe the effectiveness of coordinated rehabilitation, monitor the development or maintenance of locomotor and balance skills, and repeated assessments can signal any change in the risk of falls. A follow-up assessment provides more relevant information about the duration of the intervention effects (Geraldo et al., 2018). In the process of evaluating the results of the functional tests, we observed a trend in the time and point quantifiers of clients with similar clinical presentations; these trends allowed us to divide clients into three groups according to their FIM instrument scores performed by an occupational therapist. The effectiveness of the physiotherapy interventions was assessed relative to these groups, as well. The division of our clients according to FIM instrument proved beneficial; clients with FIM of less than 5 points required assistance from at least one person, needed to use walking aids to complete the tests, and their TUG test times were more than double the norm; two clients with the lowest FIM values (less than 4 points) were not able to complete the tests at all. FIM instrument was used by Musilová et al. (2014); they reported that comprehensive therapy of CVE patients together with intensive rehabilitation led to an improvement of overall FIM instrument values compared to baseline values, and thus increased the independence levels of patients and improved their self-sufficiency in everyday activities. This author also reported that rehabilitation therapy is indispensable, and activity measurements using FIM instrument proved to be beneficial in terms of quantifying rehabilitation therapy. Čeledová et al. (2010) agrees, noting that numerous tests are used to assess the functional status for an accurate evaluation of disability, and psychological functions and social adaptability also need to be followed. As further reported by the same author, FIM instrument is the most comprehensive tool and therefore it is more sensitive and provides more information since it evaluates the locomotion abilities and everyday activities together with cognitive functions, such as the communication ability and social aspects, at the same time.

We are obviously aware that the functional status of clients may have also improved due to spontaneous regeneration of damaged tissues. Further studies and more extensive research using larger numbers of patients are needed to derive unambiguous conclusions.

\section{The most important advantages of our study included}

Motivation due to the home setting

All clients were positive about completing the physiotherapy intervention in their home where they felt more secure and where we could use the reality and variability of the home setting (i.e., elevate a paretic arm to a height that enabled the client to open the door, or higher to open the window); we used available furniture for training (i.e., balance training next to an armchair or the fitted kitchen, training within the doorframe). An individual approach for each client was a crucial part of the intervention.

\section{Engagement of the family}

A close member was present for almost every therapy session with the client, and family members could participate in the physiotherapy. Engagement with family members was very advantageous because they could engage during self-guided therapy sessions with the client.

\section{Very close cooperation between the physiotherapist and the occupational therapist}

This was especially important for clients with a serious clinical presentation who required a lot of self-sufficiency training. Furthermore, thanks to the occupational therapeutic assessment of the FIM instrument, we were able to use this tool as a classification criterion to assess the effectiveness of interventions and modify interventions to better fit specific rehabilitation objectives. At the same time, it could be used to prescribe further rehabilitation, which is in the hands of general practitioners. Clients with FIM of more than 6 points suffered from mild disabilities, which could be managed individually through outpatient physiotherapy sessions. Clients with an FIM of less than 5 points required all-day assistance of at least one person. Therefore rehabilitation sessions might be handled best through homebased therapy, spa care or follow-up physiotherapy at rehabilitation institutes. In our study, only two of the four clients in the group had further rehabilitation after our intervention ended. Clients with an FIM of 5 to 6 points may need the supervision of another person, and any subsequent physiotherapy should be based on an individual assessment by general practitioners regarding whether home care, rehabilitation institutes or outpatient care is more beneficial for the client. In our study, 5 of 8 clients did not have subsequent rehabilitation after the intervention ended. According to the guidelines of the Ministry of Health of the Czech Republic, rehabilitation interventions should be provided to a disabled person, in the scope of the entire rehabilitation process - as long as the person's condition continues to improve $(\mathrm{MoH}$, 2010).

\section{Conclusions}

Our results, based on the longitudinal observation of postural and locomotor functions using the standardized TUG test and the BBS shows an improvement in 15 of the 17 clients with ABI during a 3-month, in-home, coordinated rehabilitation program, with no clients having a final assessment worse than their baseline assessment.

At the beginning of the study, 8 clients were at high risk of falls according to BBS; this number was reduced to three after the physiotherapeutic intervention. According to the TUG test, 12 clients were at high risk of falls initially and two clients were even unable to complete the initial test. After the in-home intervention, the number of these clients at high risk of falls decreased to 9 .

A slight worsening was observed in 11 clients in the TUG test during the first 3-month follow-up period (TUG 6). The final 3-month follow-up period (TUG 9) saw an improvement in 6 clients; nonetheless, 8 clients remained at high risk of falls. The results of both test assessments correlated; however, the interim BBS 6 assessment did not mirror the slower TUG 6 times, which indicates the higher sensitivity of the TUG test relative to postural and especially locomotor functions.

The assessment of standardized tests with respect to FIM instrument proved to be relevant, and it thus demonstrated a direct relationship with the observed trends.

Time demands of traveling to the client homes proved to be the only problematic feature of the in-home program, which was why the maximum distance was set at $30 \mathrm{~km}$. 


\section{Acknowledgements}

This work was supported by the University of South Bohemia Grant Agency under the Grant "Coordinated rehabilitation of patients with brain injury” (Reg. No. GAJU 138/2016/S).

\section{Conflict of interests}

The authors have no conflict of interests to declare.

\section{Longitudinální sledování vývoje posturálních a lokomočních funkcí u klientů po získaném poškození mozku}

\section{Souhrn}

Úvod: Získané poškození mozku netraumatického původu je onemocnění, které je přičinou těžké disability, jež s sebou nese nejen medicínské, fyzioterapeutické, ale také sociální a ekonomické problémy. Z tohoto důvodu jsme vytvořili interdisciplinární rehabilitační tým složený z lékařů, fyzioterapeutů, ergoterapeutů a sociálních pracovníků působících v domácím prostředí - ve snaze minimalizovat důsledky dlouhodobého zdravotního postižení.

Cíl: Hodnocení vývoje posturálních a lokomočních funkcí u 17 klientů se získaným poškozením mozku v časovém období 9 měsíců, u kterých byla prováděna individuální tříměsíční fyzioterapie v domácím prostředí.

Metody: K objektivizaci funkčního stavu klientů byly použity standardní testy Berg Balance Scale (BBS) a Timed Up and Go test (TUG). Hodnocení bylo prováděno při vstupu do studie, dále po 3, 6 a 9 měsících - celkem 4 měření u každého klienta.

Výsledky: Na základě vyhodnocení testů BBS a TUG došlo po tříměsíční intervenci u 15 klientů k výraznému zlepšení jejich balančních funkcí; 2 klienti nebyli schopni dokončit TUG test a 6 klientů zůstalo stále ohroženo pádem.

Závěr: Z longitudinálního sledování vývoje posturálních a lokomočních funkcí u klientů s poškozením mozku je jednoznačný benefit tříměsíční fyzioterapeutické intervence v jejich domácím prostředí. S odstupem půl roku po ukončení terapie je ale téměř u třetiny klientů zřejmé mírné zhoršení v testu TUG, naopak v BBS se všech 15 klientů dále zlepšovalo, což může poukazovat na větší citlivost testu TUG pro hodnocení balančních funkcí. Proto by bylo vhodné fyzioterapeutickou intervenci prodloužit na delší časový úsek, hlavně u klientů, kteří mají FIM pod 6 stupňů.

Klíčová slova: BBS; FIM; hodnocení stability; riziko pádů; TUG test; získané poškození mozku

\section{References}

1. Algwiri AA, Whitney SL (2012). Balance and Falls. Geriatric Physical Therapy. 3rd ed. St. Louis, MO: Elsevier, 331-353. [online] [cit. 2020-01-22]. Available from: https://www. chirocredit.com/downloads/geriatricrehab/geriatricrehab110 pdf

2. Ambler Z (2011). Základy neurologie: učebnice pro lékařské fakulty. 7th ed. Praha: Galén.

3. Andersson AG, Kamwendo K, Seiger A, Appelros P (2006). How to identify potential fallers in a stroke unit: validity indexes of 4 test methods. J Rehabil Med 38(3): 186-191. DOI: 10.1080/16501970500478023.

4. Barry E, Galvin R, Keogh C, Horgan F, Fahey T (2014). Is the Timed Up and Go test a useful predictor of risk of falls in community dwelling older adults: a systematic review and metaanalysis. BMC Geriatr 14: 14. DOI: 10.1186/1471-2318-14-14.

5. Berg KO, Wood-Dauphinee SL, Williams JI, Guiton D (1989). Measuring Balance in the Elderly: Preliminary development of an Instrument. Physiother Can 41(6): 304-311. DOI: 10.3138/ ptc.41.6.304.

6. Berg KO, Wood-Dauphinee SL, Williams JI, Maki B (1992). Measuring balance in the elderly: Validation of an instrument. Can J Public Health 83(Suppl. 2): S7-S11.

7. Bizovská L, Janura M, Míková M, Svoboda Z (2017). Rovnováha a možnosti jejího hodnocení. Olomouc: Univerzita Palackého v Olomouci.

8. Bohannon RW (2006). Reference values for the timed up and go test: a descriptive meta-analysis. J Geriatr Phys Ther 29(2): 64-68. DOI: 10.1519/00139143-200608000-00004.

9. Burget $\mathrm{N}$ (2015). Využití zpětné vazby v rehabilitaci pacientů $\mathrm{s}$ poruchami chůze po cévní mozkové příhodě. Rehabil Fyz Lék 22(2): 70-78.

10. Carraro L (2002). Obnova pohybu po cévní mozkové př́íhodě. Praha: Rehalb o.p.s.
11. Čeledová L, Čevela R (2011). Future of coordinated rehabilitation (complete, comprehensive). Prakt Lék 91(11): 653-656.

12. Čeledová L, Čevela R. Kalita Z, Vaňásková E (2010). Posuzování zdravotního stavu a pracovní schopnosti osob po cévní mozkové příhodě - kazuistiky. Česká a slovenská neurologie a neurochirurgie 73/106(6): 728-733.

13. Dungl P (2005). Biomechanika chůze. In: Dungl P, et al. Ortopedie. Grada Publishing.

14. Geraldo A, Dores AR, Coelho B, Ramião E, Castro-Caldas A, Barbosa F (2018). Efficacy of ICT-based neurocognitive rehabilitation programs for acquired brain injury: A systematic review on its assessment methods. Eur Psychol 23(3): 250-264. DOI: 10.1027/1016-9040/a000319.

15. Hlinovský D, Doležalová I, Hlinovská J (2016). Komplexní rehabilitace pacientů po cévní mozkové příhodě - projekt iktového centra Thomayerovy nemocnice. Prakt Lék 96(6): 267-271.

16. IHIS CR - Institute of Health Information and Statistics of the Czech Republic (2018). Hospitalizovaní v nemocnicích ČR 2017. Zdravotnická statistika ČR. [online] [cit. 2020-01-22]. Available from: https://www.uzis.cz/index.php?pg=record\&id=8100

17. Kolář P, et al. (2012). Rehabilitace v klinické praxi. Praha: Galén.

18. Kolář P, Máček M, et al. (2015). Základy klinické rehabilitace. Praha: Galén.

19. Lippertová-Grünerová M (2015). Rehabilitace po náhlé cévní mozkové př́ihodě. Praha: Galén.

20. Mayer M (2002). Paradoxy v neurokineziologii spastické chůze. Rehab Fyz Lék 7(2): 66-73.

21. McIntyre A, Janzen S, Richardson M, Kwok C, Teasell R (2015). An Overview of Acquired Brain Injury Rehabilitation Randomized Controlled Trials. J Head Trauma Rehabil 30(6): E47-53. DOI: 10.1097/HTR.0000000000000108.

22. Mikula J (2008). Rehabilitace po CMP. Kardiol Rev Int Med 10(2): 66-73. 
23. MoH - Ministry of Health of the Czech Republic (2010). Péče o pacienty s cerebrovaskulárním onemocněním v České republice. 2: 2-10. [online] [cit. 2020-01-22]. Available from: https://www.cmp.cz/jnp/cz/pece_o_cmp_v_cr/ cerebrovaskularni_pece_v_cr.html

24. MoH - Ministry of Health of the Czech Republic (2015). Seznam center vysoce specializované zdravotní péče o pacienty s iktem. 11: 55-56. [online] [cit. 2020-01-22]. Available from: https://www.cmp.cz/public/5f/f3/e9/4809_21789_ ZDRAVOTNICTVI_11_15_1_.pdf

25. Musilová E, Žiaková E, Letašiová D (2014). Fyzioterapie u pacientů po cévní mozkové prríhodě. Rehab Fyz Lék 21(3): 136-140.

26. Podsiadlo D, Richardson S (1991). The Timed "Up \& Go": a Test of Basic Functional Mobility for Frail Elderly Persons. J Am Geriatr Soc 39(2): 142-148. DOI: 10.1111/j.1532-5415.1991. tb01616.x.
27. Rehabilitation measures database (2010). The Rehabilitation Clinician's Place to Find the Best Instruments to Screen Patients and Monitor Their Progress. Rehabilitation Institute of Chicago. [online] [cit. 2019-10-01]. Available from: http:// www.rehabmeasures.org/ and from: https://www.sralab.org/ rehabilitation-measures/timed-and-go

28. Son H, Park CH (2018). Effect of turning direction on Timed Up and Go test results in stroke patients. Eur J Phys Rehabil Med 55(1): 35-39. DOI: 10.23736/S1973-9087.18.05202-4.

29. The FIM Instrument: Its Background, Structure, and Usefulness (2014). Buffalo: UDS MR [online] [cit. 2018-09-11]. Available from: http://www.udsmr.org/Documents/The_FIM_ Instrument_Background_Structure_and_UsUsefUsUs.pdf

30. Vařeka I (2002). Posturální stabilita (I. část): Terminologie a biomechanické principy. Rehab Fyz Lék 9(4): 115-121. 